\title{
PENGARUH SISTEM OLAH TANAH DAN APLIKASI MULSA BAGAS PADA PERTANAMAN TEBU (Saccharum officinarum L.) TERHADAP POPULASI MIKROORGANISME PELARUT FOSFAT DI PT. GMP LAMPUNG TENGAH
}

\author{
Nyang Vania Ayuningtyas Harini, Ainin Niswati \& Sri Yusnaini \\ Jurusan Agroteknologi, Fakultas Pertanian Universitas Lampung \\ Jl.Prof. Soemantri Brodjonegoro, No.1, Bandar Lampung 35145 \\ E-mail:nyang.vania@yahoo.com
}

\begin{abstract}
Sugarcane plantation atPT Gunung Madu Plantation (GMP) has done intensive tillage since 1975. To maintain sustainable production and soil fertility is necessary to manage soil according to good soil conservation. The good choice to maintaince soil quality is no-tillage and mulching system. The research was carried out since July 2010,phosphate solubilizing microorganismwere observedat 9 and 12 months after ratoon one, in April and July 2012. The research was designed as a split plot with a randomized block design (RBD) with 5 replications . Main plot are tillage system that consists of no-tillage $\left(\mathrm{T}_{0}\right)$ and tillage $\left(\mathrm{T}_{1}\right)$. The subplots were application of baggase mulch. Consisting ofwithout bagasse mulch application $\left(\mathrm{M}_{0}\right)$ andwith $80 \mathrm{t} \mathrm{ha}^{-1}$ baggase mulch $\left(\mathrm{M}_{1}\right)$. Data were analyzed by analysis of variance at the level of $1 \%$ and $5 \%$, which previously had been analyzed with the Bartlett test forHomogeneity and Additivity with Tukey test, and followed by LSD test at the level of $1 \%$ and $5 \%$. The results showed that the tillage system and bagasse mulch application did not give significant effect on the population of phosphate solubilizing microorganism. Correlation test results showed that the phosphate solubilizing microorganism population has no correlation with organic $\mathrm{C}$, total $\mathrm{N}$, soil $\mathrm{pH}$, soil moisture, soil temperature, and available-P.
\end{abstract}

Keywords: Bagasse mulch, Saccharum officinarum L., phosphate solubilizing microorganism,tillage systems

\section{PENDAHULUAN}

Peningkatan produksi tebu dengan melakukan perbaikan kondisi tanah sangat diperlukan terutama di PT. GMP Lampung Tengah.Perusahaan ini telah mengusahakan perkebunan tebu sejak 1975 yang terus menerus melakukan pertanian intensif dengan pengolahan tanah dan penggunaan bahan-bahan kimia seperti pupuk dan pestisida (PT.GMP, 2009).Meskipun pekerjaan mengolah tanah secara teratur dianggap penting, tetapi pengolahan tanah secara intensif dapat menyebabkan terjadinya degradasi tanah yang diikuti kerusakan struktur dan tekstur tanah, peningkatan terjadinya erosi tanah, dan penurunan kandungan bahan organik dalam tanah yang berpengaruh terhadap keberadaan biota tanah (Umar, 2004).

Salah satu usaha untuk mempertahankan kesuburan tanah bagi pertumbuhan tanaman adalah dengan membiarkan tanah sementara tanpa diolah dan pemberian mulsa organik (Utomo, 2006).Mulsa organik yang dapat digunakan di PT. GMP adalah Bagas. Bagas merupakan limbah pertama yang dihasilkan dari proses pengolahan industri gula tebu, volumenya mencapai 30-
40\% dari tebu giling (Agustina, 2008). Bagas terdiri dari air, serat, dan padatan terlarut dalam jumlah relatif kecil. Mulsa bagas memegang peranan penting dalam memperbaiki sifat tanah yang selanjutnya akan meningkatkan produktivitas tanah dan tanaman. Bagas dapat memperbaiki infiltrasi, porositas, struktur tanah, ketersediaan unsur hara, dan merupakan sumber energi bagi mikroorganisme tanah (Agustina, 2008).

Segala perlakuan yang diberikan ke dalam tanah akan mempengaruhi sifat-sifat tanah, terutama sifat biologis tanah. Salah satu sifat biologis tanah yaitu keberadaan mikroorganisme pelarut fosfat.Peranan MPF di dalam tanah adalah membantu melarutkan $\mathrm{P}$ yang umumnya dalam bentuk tidak larut dalam tanah sehingga dapat digunakan oleh tanaman.Mikroorganisme pelarut fosfat umumnya ditemukan sebagai pelarut anorganik, yaitu berkisar antara $10^{-4}$ sampai $10^{-6}$ sel per gram tanah (Gaur, 1980 dalam Santosa 1997). Marlina (1997), melaporkan bahwa persentase bakteri pelarut fosfat terhadap total bakteri tanah adalah $0,03 \%$ sampai dengan $0,11 \%$.Dengan pemberian bahan organik dalam hal ini bagas, keefektifan mikroorganisme pelarut fosfat akan meningkat. Mikroorganisme pelarut fosfat akan 
menggunakan bagas sebagai sumber energi untuk mendukung peningkatan aktivitasnya dalam tanah.

Penelitian ini bertujuan untuk mempelajari pengaruh sistem olah tanah dan aplikasi mulsa bagas pada lahan pertanaman tebu (Saccharum officinarum L.) terhadap populasi mikroorganisme pelarut fosfat di PT. Gunung Madu Plantation, Lampung Tengah.

\section{BAHAN DAN METODE}

Penelitian ini dilaksanakan di lahan perkebunan tebu di PT Gunung Madu Plantation (GMP) sejak Juli 2010. Pengamatan MPF dilakukan pada bulan April 2012 dan September 2012, yaitu pada ratoon pertama atau musim tanam ke-2.Pengamatan Mikroorganisme Pelarut Fosfat (MPF) dilakukan di Laboratorium Bioteknologi, Fakultas Pertanian, Universitas Lampung.Analisis tanah dilakukan di Laboratorium Ilmu Tanah, Fakultas Pertanian, Universitas Lampung.

Penelitian ini dirancang secara split plot dalam rancangan acak kelompok (RAK) dengan 5 ulangan. Petak utama yaitu sistem olah tanah, yang terdiri dari tanpa olah tanah $\left(\mathrm{T}_{0}\right)$ dan olah tanah intensif $\left(\mathrm{T}_{1}\right)$. Sebagai anak petak adalah aplikasi mulsa bagas terdiri dari: tanpa aplikasi mulsa bagas $\left(\mathrm{M}_{0}\right)$ dan aplikasi mulsa bagas 80 tha $^{-1}\left(\mathrm{M}_{1}\right)$.Sehingga terbentuk 4 kombinasi perlakuanyaitu :

$\mathrm{T}_{0} \mathrm{M}_{0}=$ tanpa olah tanah + tanpa mulsa bagas (kontrol), $\mathrm{T}_{0} \mathrm{M}_{1}=$ tanpa olah tanah + mulsa bagas 80 tha $^{-1}, \mathrm{~T}_{1} \mathrm{M}_{0}=$ olah tanah intensif + tanpa mulsa bagas, $\mathrm{T}_{1} \mathrm{M}_{1}=$ olah tanah intensif + mulsa bagas 80 tha $^{-1}$.

Data yang diperoleh dianalisis dengan sidik ragam pada taraf $1 \%$ dan $5 \%$, yang sebelumnya telah diuji homogenitas ragamnya dengan uji Bartlett dan aditivitasnya dengan uji Tukey.Rata-rata nilai tengah diuji dengan uji BNT pada taraf $1 \%$ dan 5\%.Uji korelasi dilakukan untuk mengetahui hubungan antara populasi mikroorganisme pelarut fosfat (MPF) denganC-organik tanah, $\mathrm{pH}$ tanah, kelembaban tanah, suhu tanah, $\mathrm{N}$-total tanah, dan P-tersedia.

Pabrik tebu di PT.Gunung Madu Plantations (GMP) didirikan pada tahun 1975, merupakan pelopor usaha perkebunan dan pabrik gula di luar Jawa, khususnya Lampung. Areal perkebunan tebu dan pabrik gula PT. GMP terletak di Desa Gunung Batin, Lampung Tengahsekitar $90 \mathrm{~km}$ arah utara kota Bandar Lampung.Luas areal PT. GMP yang dikelola $36.000 \mathrm{ha}$, dengan luas kebun produksi sekitar 25.000 ha.

Penelitian yang masih dilakukan adalahsistem olah tanah intensif dan tanpa olah tanah, serta aplikasi limbah padat pabrik gula bagas, blotong dan abu
(BBA).Tanaman tebu ditanam pada bulan Juli 2010.Ratoon pertama ditanam pada ada tanggal 21 Juli 2011 varietas RGM 00-838. Pupuk yang diaplikasikan adalah pupuk urea dengan dosis $300 \mathrm{kgha}^{-}$ ${ }^{1}$, dan pupuk TSP $200 \mathrm{kgha}^{-1}$, pupuk MOP (Muriate of Potash) $300 \mathrm{kgha}^{-1}$, dan aplikasi bagas, blotong, dan abu (BBA) segar (5:3:1) 80 tha $^{-1}$.

Pengambilan contoh tanah dapat dilakukan dengan teknik pengambilan contoh tanah secara utuh/tak terusik. Pengambilan contoh tanah dengan bor tanah dari 12 titik pada masing-masing plot percobaan dengan kedalaman $20 \mathrm{~cm}$ dan kemudian dikompositkan. Contoh tanah diambil secara melingkar dengan titik tengah plot sebagai pusatnya, empat titikberjarak $3 \mathrm{~m}$ dari titik pusat, dan delapan titik berjarak $4 \mathrm{~m}$ dari titik pusat. Pengambilan contoh tanah awal pada bulan April 2012 dan pengambilan contoh tanah kedua pada bulan Juni 2012.

Isolasi dilakukan dengan seri pengenceran dan teknik cawan tuang dengan menggunakan medium agar Pikovskaya dengan komposisi per liter sebagai berikut : $\mathrm{Ca}_{3}\left(\mathrm{PO}_{4}\right)_{2}(5 \mathrm{~g}), \mathrm{NaCl}(0,2 \mathrm{~g}), \mathrm{KCl}(0,2 \mathrm{~g})$, $\mathrm{MgSO}_{4} \cdot 7 \mathrm{H}_{2} \mathrm{O}(0,1 \mathrm{~g}), \mathrm{MnSO}_{4} \cdot 7 \mathrm{H}_{2} \mathrm{O}(0,0025 \mathrm{~g})$, $\mathrm{FeSO}_{4} .7 \mathrm{H}_{2} \mathrm{O}(0,0025 \mathrm{~g}),\left(\mathrm{NH}_{4}\right) 2 \mathrm{SO}_{4}(0,5 \mathrm{~g})$, glukosa $(10 \mathrm{~g})$, yeast ekstrak $(0,5 \mathrm{~g})$, agar $(15 \mathrm{~g})$, dan aquades 1 L (Rao,1994).Seri pengenceran tanah dilakukan dengan cara memasukkan $10 \mathrm{~g}$ tanah ke dalam $90 \mathrm{ml}$ larutan fisiologis $(8,5 \mathrm{NaCl}$ dalam $1 \mathrm{~L}$ aquades $)$ yang telah diautoklaf (pengenceran $10^{-1}$ ). Dari pengenceran $10^{-1}$ diambil $1 \mathrm{ml}$ dan dimasukkan ke dalam $9 \mathrm{ml}$ larutan fisiologis steril (pengenceran $10^{-2}$ ) dan seterusnya hingga pengenceran $10^{-5}$. Dari setiap pengenceran diambil 1 $\mathrm{ml}$ dan diinokulasikan ke dalam cawan petri yang sebelumnya sudah diisi dengan media Pikovskaya steril. Inkubasi dilakukan pada inkubator pada suhu $28^{\circ} \mathrm{C}$ selama 4-7 hari. Pengamatan koloni mikroorganisme pelarut fosfat pada cawan petri dilakukan dengan ciri-ciri terdapat bagian bening atau transparan pada tepian koloni dan dihitung jumlahnya (Nurkanto, 2007).

Variabel pendukung yang diamati pada penelitian ini adalah $\mathrm{pH}$ tanah $\left(\mathrm{H}_{2} \mathrm{O}\right)$, C-organik (\%) menggunakan metode Walkley and Black, $\mathrm{N}$-total (\%) menggunakan metode Kjeldahl, Kadar air tanah (\%) menggunakan metode Gravimetrik, P-tersedia (ppm) menggunakan metode Bray-1. Serta suhu tanah dan kelembaban tanah.

\section{HASIL DAN PEMBAHASAN}

Pada Gambar 1. tampak bahwa populasi MPF dilahan pertanaman tebu pada umumnya rendah berkisar antara 3,60-3,87 log CFU $100^{-1} \mathrm{~g}$ jika dibandingkan dengan hasil penelitian Fitriyatin (2009) pada lahan 
tanaman padi berkisar antara 6,65-6,71 log CFU 100-1 g. Hasil uji BNT antar perlakuan yaitu sistem olah tanah dan pemberian mulsa bagas tidak nyata pengaruhnya terhadap pertumbuhan MPF.Belum adanya pengaruh sistem olah tanahterhadap populasi MPF diduga karena kandungan P-tersedia yang cukup tinggi yaitu antara 104,35 ppm sampai 157,01 ppm (Tabel 1). Tingginya Ptersedia di dalam tanah disebabkan oleh pemberian pupuk $P$ yang berlebihan pada lahan tebu tersebut. Sehingga memungkinkan aktivitas MPF berkurang. Selain itu, populasi MPF juga dipengaruhi oleh faktor lingkungan seperti pH tanah.Menurut Paul dan Clark (1989), pertumbuhan mikroorganisme di dalam tanah dipengaruhi oleh $\mathrm{pH}$ tanah, dan temperatur.Dari hasil analisis $\mathrm{pH}$ tanah, pada perlakuan OTM (olah tanah minimum) berkisar antara 4,25-5,23 (masam), sedangkan pada perlakuan OTI (olah tanah intensif) berkisar antara 4,285,45 termasuk dalam kriteria masam (Tabel 1).Pada kisaran nilai $\mathrm{pH}$ ini menunjukkan bahwa kondisi tanah di lokasi penelitian memiliki sifat masam, sehingga kurang cocok untuk pertumbuhan MPF. Budiyanto (2010) menyatakan bahwa pH optimum yang sesuai untuk pertumbuhan mikroorganisme berkisar antara 6,5 (agak masam)- 7,5 (netral). Suhu yang sesuai untuk pertumbuhan mikroorganisme berkisar antara $35-37{ }^{\circ} \mathrm{C}$ (Sutiknowati, 2010). Namun, hasil pengukuran suhu di lahan menunjukkan bahwa OTM (olah tanah minimum) berkisar antara $24,8-29,6^{\circ} \mathrm{C}$ dan OTI (olah tanah intensif)

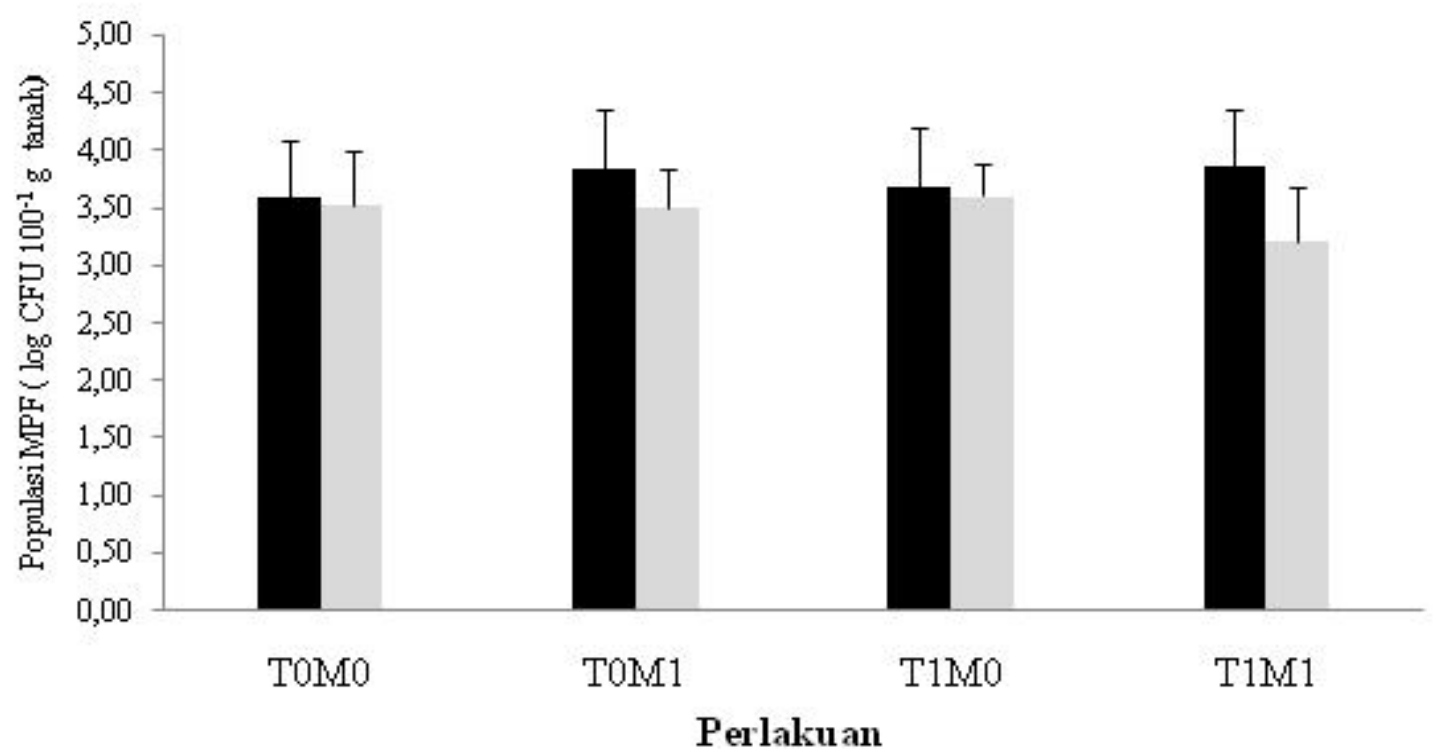

Gambar 1. Populasi MPF pada lahan pertanaman tebu pada saat tebu berumur 9 BSRt $_{1}$ dan 12 BSRt $_{1}$.Keterangan $: \mathrm{T}_{0}=$ Tanpa olah tanah $; \mathrm{T}_{1}=$ Olah tanah intensif; $\mathrm{M}_{0}=$ Tanpa mulsa $; \mathrm{M}_{1}=$ Mulsa, $\mathrm{BSRt}_{1}=$ Bulan setelah ratoon satu. Tongkat pada grafik menujukkan standar deviasi. $\mathbf{E}=9$ BSRT1, $=12$ BSRT1.

Tabel 1. Hasil analisis sifat tanah pada saat tanaman tebu berumur $9 \mathrm{BSRt}_{1}$ dan $12 \mathrm{BSRt}_{1}$.

\begin{tabular}{|c|c|c|c|c|c|c|c|c|c|c|c|c|}
\hline \multirow{4}{*}{ Perlakuan } & \multicolumn{12}{|c|}{ Variabel pengamatan } \\
\hline & \multicolumn{2}{|c|}{$\begin{array}{c}\text { C-organik } \\
(\%)\end{array}$} & \multicolumn{2}{|c|}{$\begin{array}{c}\mathrm{N} \text {-total } \\
(\%)\end{array}$} & \multicolumn{2}{|c|}{$\begin{array}{c}\mathrm{pH} \\
\left(\mathrm{H}_{2} \mathrm{O}\right)\end{array}$} & \multicolumn{2}{|c|}{$\begin{array}{l}\text { Suhu } \\
\left({ }^{\circ} \mathrm{C}\right)\end{array}$} & \multicolumn{2}{|c|}{$\begin{array}{c}\text { Kelembaban } \\
(\%)\end{array}$} & \multicolumn{2}{|c|}{$\begin{array}{l}\text { P-tersedia } \\
\text { (ppm) }\end{array}$} \\
\hline & 9 & 12 & 9 & 12 & 9 & 12 & 9 & 12 & 9 & 12 & 9 & 12 \\
\hline & $\mathrm{BSRt}_{1}$ & $\mathrm{BSRt}_{1}$ & $\mathrm{BSRt}_{1}$ & $\mathrm{BSRt}_{1}$ & $\mathrm{BSRt}_{1}$ & $\mathrm{BSRt}_{1}$ & $\mathrm{BSRt}_{1}$ & $\mathrm{BSRt}_{1}$ & $\mathrm{BSRt}_{1}$ & $\mathrm{BSRt}_{1}$ & $\mathrm{BSRt}_{1}$ & $\mathrm{BSRt}_{1}$ \\
\hline $\mathrm{T}_{0} \mathrm{M}_{0}$ & 0,98 & 1,09 & 0,08 & 0,20 & 4,33 & 5,12 & 27,90 & 25,40 & 8,60 & 6,40 & 145,56 & 157,01 \\
\hline $\mathrm{T}_{0} \mathrm{M}_{1}$ & 1,19 & 1,18 & 0,07 & 0,19 & 4,31 & 5,19 & 27,72 & 25,30 & 10,40 & 6,40 & 141,57 & 139,56 \\
\hline $\mathrm{T}_{1} \mathrm{M}_{0}$ & 1,04 & 0,92 & 0,08 & 0,18 & 4,72 & 5,13 & 27,34 & 24,98 & 8,20 & 6,00 & 113,79 & 104,35 \\
\hline $\mathrm{T}_{1} \mathrm{M}_{1}$ & 1,06 & 1,12 & 0,07 & 0,16 & 4,97 & 5,29 & 28,36 & 25,14 & 11,00 & 6,80 & 122,11 & 124,68 \\
\hline
\end{tabular}

Keterangan : $\mathrm{T}_{0}=$ Tanpa olah tanah, $\mathrm{T}_{1}=$ Olah tanah intensif, $\mathrm{M}_{0}=$ Tanpa mulsa, $\mathrm{M}_{1}=$ Mulsa. 
berkisar antara $24,6-30,6^{\circ} \mathrm{C}$. Sehingga mempengaruhi pertumbuhan mikroorganisme yang ada di dalam tanah tersebut.

Perlakuan sistem tanpa olah tanah dan aplikasi mulsa bagas tidak berpengaruh terhadap populasi MPF, hal ini diduga karna pemberian mulsa yang baru diterapkan belum berpengaruh terhadap populasi MPF. Mulsa bagas yang digunakan mempunyai kandungan C/ $\mathrm{N}$ rasio yang relatif tinggi sekitar 86 (Sucipto, 2011). Waktu penelitian yang baru berjalan 2 tahun membuat mulsa bagas belum terdekomposisi secara keseluruhan menjadi C-organik tanah dan unsur hara lainnya, karena waktu yang dibutuhkan untuk pembentukan C-organik tanah cukup lama. Secara alami pengomposan akan berlangsung beberapa minggu hingga 3 tahun hingga kompos benar-benar matang (Isroi, 2008). Menurut Atmojo (2003) proses pengomposan adalah suatu proses penguraian bahan organik dari nisbah $\mathrm{C} / \mathrm{N}$ tinggi (mentah) menjadi bahan yang mempunyai nisbah $\mathrm{C} / \mathrm{N}$ kurang dari 15 (matang).

Selain itu, sistem olah tanah yang diterapkan baru berjalan 2 tahun,membuat kondisi tanah pada perlakuan tanpa olah tanah belum berbeda dengan perlakuan olah tanah intensif. Dalam kurun waktu 2 tahun perlakuan tanpa olah tanah belum dapat memperbaiki kesuburan tanah tersebut. Sistem olah tanah intensif yang diterapkan olah PT. GMP selama \pm 20 tahun, sehingga mempengaruhi keberadaan biota tanah. Perlakuan sistem olah tanah intensif diduga menyebabkan kerusakan tanah yang mempengaruhi aktivitas mikroorganisme. Penelitian ini ditegaskan dengan penelitian Batubara (2012), yang telah melakukan pengamatan pada tahun ke-2, dari hasil penelitian menunjukkan bahwa belum adanya pengaruh dari sistem olah tanah dan aplikasi mulsa bagas terhadap populasi dan biomassa cacing tanah.

Pada Gambar 2. menunjukkan koloni MPF pada medium Pikovskaya. Ciri-ciri MPF yang diperoleh dari hasil isolasi adalah zona bening (halozone) disekitar koloni mikroorganisme yang tumbuh pada media Pikovskaya, bentuk koloni tidak teratur, memiliki bentuk tepian berombak, dengan ukuran diameter $\pm 1 \mathrm{~cm}$, dan berwarna putih. Waktu yang diperlukan untuk pertumbuhan, warna dan besar koloni serta luas daerah bening berbeda-beda tergantung dari jenis MPF.Pembentukan zona bening menandakan bahwa bakteri dapat menghasilkan enzim ekstraseluler yaitu fosfatase dan asam organikseperti asam formiat, asetat, propionat, laktat, glikolat, fumarat dan suksinat (Hilda and Faga, 2000).Selanjutnya, asam-asam organik ini akan bereaksi dengan bahan pengikat fosfat seperti $\mathrm{Al}^{3+}, \mathrm{Fe}^{3+}$, $\mathrm{Ca}^{2+}$ dan $\mathrm{Mg}^{2+}$ membentuk khelat organik yang stabil sehingga mampu membebaskan ion fosfat terikat dan dapat diserap tanaman. Semakin luas dan semakin jernih pembentukan daerah bening, secara kualitas menunjukkan semakin tinggi kelarutan fosfat dalam media, sehingga koloni tersebut dapat dipilih atau diisolasi sebagai isolat atau strain MPF yang mempunyai potensi untuk dapat dikembangkan lebih lanjut.

Pada Tabel 2 menunjukkan populasi MPF tidak menunjukkan korelasi yang nyata terhadap C-organik, $\mathrm{N}$-total, $\mathrm{pH}$ tanah, suhu tanah, kelembaban tanah, dan $\mathrm{P}$-tersedia.Hal ini diduga karena kandungan $\mathrm{C} / \mathrm{N}$ rasio bagas yang relatif tinggi sekitar 86 (Sucipto, 2011). Disamping itu, waktu penelitian yang baru berjalan 2 tahun membuat mulsa bagas belum terdekomposisi secara keseluruhan menjadi C-organik tanah dan unsur hara lainnya, karena waktu yang diperlukan untuk pembentukan C-organik tanah cukup lama (Cahyono, 2013). Hal ini ditegaskan dengan penelitian Sarno (2003) yang menyatakan bahwa pemberian bahan organik berkualitas rendah $(\mathrm{C} / \mathrm{N})$ ke dalam tanah akan melepaskan unsur hara secara lambat.

Selain itu, populasi mikroorganisme pelarut fosfat juga dipengaruhi oleh faktor lingkungan seperti : $\mathrm{pH}$, kelembaban, dan suhu diareal pertanaman tebu. Seperti

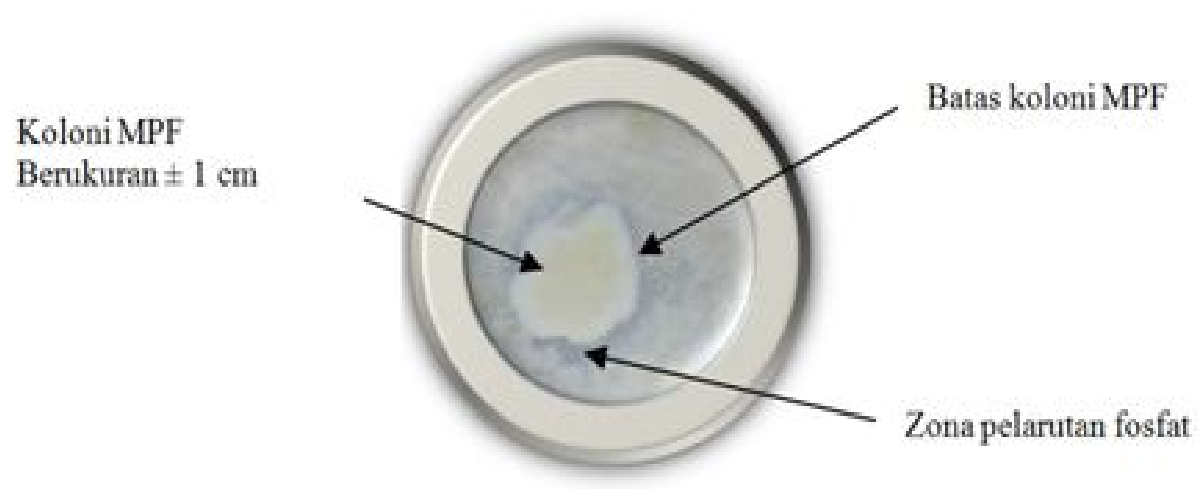

Gambar 2. Hasil isolasi MPF yang membetuk zona bening 
Tabel 2. Korelasi antara populasi MPF dengan kadar C-organik, N-total, pH tanah, suhu tanah, kelembaban tanah, dan P-tersedia pada saat tanaman tebu berumur $9 \mathrm{BSRt}_{1}$ dan $12 \mathrm{BSRt}_{1}$

\begin{tabular}{lcc}
\hline \multirow{2}{*}{ Variabel } & \multicolumn{2}{c}{ Populasi MPF } \\
\cline { 2 - 3 } & \multicolumn{2}{c}{ Nilai r } \\
\cline { 2 - 3 } & 9 BSRt $_{1}$ & 12 BSRt $_{1}$ \\
\hline C-organik & $0,21^{\text {tn }}$ & $-0,35^{\text {tn }}$ \\
N-total & $0,01^{\text {tn }}$ & $0,01^{\text {tn }}$ \\
pH tanah & $0,21^{\text {tn }}$ & $-0,16^{\text {tn }}$ \\
Suhu & $0,12^{\text {tn }}$ & $-0,25^{\text {tn }}$ \\
Kelembaban & $0,18^{\text {tn }}$ & $-0,09^{\text {tn }}$ \\
P-tersedia & $-0,19^{\text {tn }}$ & $-0,30^{\text {tn }}$ \\
\hline
\end{tabular}

Keterangan: $\mathrm{tn}=$ tidak nyata.

yang dikemukakan oleh Setiadi (1989), mikrobadisekitar tanah populasinya tergantung kepada kepekaanmikroba itu sendiri, kesuburan tanah, kelembaban, dan intensitas cahaya, serta temperatur tanah.Dari hasil analisis $\mathrm{pH}$ tanah, pada perlakuan OTM (olah tanah minimum) berkisar antara 4,25-5,23 (masam), sedangkan pada perlakuan OTI (olah tanah intensif) berkisar antara 4,28-5,45 (masam).Pada kisaran nilai $\mathrm{pH}$ ini menunjukkan bahwa kondisi tanah dilokasi penelitian memiliki sifat masam, sehingga kurang cocok untuk pertumbuhan MPF.Budiyanto (2010) menyatakan bahwa $\mathrm{pH}$ optimum yang sesuai untuk pertumbuhan mikroorganisme berkisar antara 6,5 (agak masam) -7,5 (netral). Suhu yang sesuai untuk pertumbuhan mikroorganisme berkisar antara $35-37^{\circ} \mathrm{C}$ (Sutiknowati, 2010). Namun, hasil pengukuran suhu di lahan menunjukkan bahwa OTM (olah tanah minimum) berkisar antara $24,8-29,6^{\circ} \mathrm{C}$, dan OTI (olah tanah intensif) berkisar antara $24,6-30,6^{\circ} \mathrm{C}$. Sehingga mempengaruhi pertumbuhan mikroorganisme yang ada di dalam tanah tersebut.

Selain itu, kandungan P-tersedia yang cukup tinggi didalam tanah berkisar antara 104,35 ppm sampai 157,01 ppm, hal ini menyebabkan keberadaan MPF didalam tanah berkurang. Fungsi MPF disini adalah untuk melarutkan bentuk P tidak larut dalam tanah sehingga siap diserap oleh tanaman. Apabila kandungan Ptersedia dalam tanah tinggi, maka MPF tidak berperan lagi dalam melarutkan P. Penelitian ini sejalan dengan hasil penelitian Listyowati (2013) yaitu tingginya kadar P-tersedia dalam tanah menyebabkan terhambatnya perkembangan FMA didalam tanah.

\section{KESIMPULAN}

Simpulan yang diperoleh dari hasil penelitian adalah:sistem olah tanah pada pertanaman tebu tidak mempengaruhi populasi mikroorganisme pelarut fosfat pada saat tanaman tebu berumur 9 dan 12 bulan setelah ratoon 1.Aplikasi mulsa bagas pada pertanaman tebu tidak mempengaruhi populasi mikroorganisme pelarut fosfat pada saat tanaman tebu berumur 9 dan 12 bulan setelah ratoon 1.Tidak terdapat interaksi antara sistem olah tanah dan pemberian mulsa bagas terhadap populasi mikroorganisme pelarut fosfat.Tidak terdapat korelasi antara C-organik, N-total, kelembaban, suhu, $\mathrm{pH}$, serta P-tersedia terhadap populasi MPF.

\section{DAFTAR PUSTAKA}

Agustina. 2008. Isolasi dan Uji Aktivitas Selulose Mikroba Termofilik dari Pengomposan ampas Tebu (Baggase). Skripsi. Universitas Lampung. Bandar Lampung. $64 \mathrm{hlm}$.

Atmojo, A. 2003. Pengomposan Kulit Nanas Menggunakan Starter Mikroorganisme Efektif dan Bokashi dalam Kondisi pH Asam dan Netral. J Biota. 7(3): 131-138.

Batubara, M. H. 2012. Pengaruh Sistem Olah Tanah dan Aplikasi Mulsa Bagas terhadap Biomassa Cacing Populasi dan Biomassa Cacing Tanah pada Pertanaman Tebu (Saccharum officinarumL.) Tahun Ke 2. Skripsi. Universitas Lampung. Bandar Lampung. 59 hlm. 
Budiyanto. 2010. Pertumbuhan Mikroorganisme. Blog pendidikan biologi dalam http:// zaifbio.wordpress.com/category/mikrobiologi/, diakses pada 15 Mei 2013.

Cahyono, B. 2013. Pengaruh Sistem Olah Tanah dan Aplikasi Mulsa Bagas terhadap Respirasi Tanah pada Lahan Pertanaman Tebu (Saccharum officinarum L.)PT. Gunung Madu Plantations (GMP).Skripsi. Universitas Lampung. Bandar Lampung. $50 \mathrm{hlm}$.

Fitriyatin, N.B.2009. Pengaruh Mikroba Pelarut Fosfat dan Pupuk $\mathrm{P}$ terhadap Aktivitas Fosfatase, $\mathrm{P}$ Tanaman dan Hasil Padi Gogo (Oryza sativa L.) pada Ultisol.J Agrikultura.20 (3): 210-215.

Hilda, R., and R. Faga. 2000. Phosphate Solubilizing Bacteria andtheir Role in Plant Growth Promotion. Departement of Microbiology, CubanResearch Institute On Sugarcane ByProducts (ICIDCA), P.O.Box 4026,CP 11000, Havana, Cuba. http://www.molecular-plantbiotechnology.Diakses tanggal27 Mei 2013.

Isroi. 2008. Kompos. Makalah. Balai Penelitian Bioteknologi Perkebunan Indonesia, Bogor. http:/ /isroi.com/2008/02/20/makalah-tentang-kompos/ , diakses pada tanggal 29 Mei 2013.

Listyowati, M. S. 2013. Pengaruh Sistem Olah Tanah Dan Pemberian Mulsa Bagas Terhadap Populasi Fungi Mikoriza Arbuskula Pada Perkebunan Tebu (Saccharum officinarum L.) Di PT Gunung Madu Plantations. Skripsi. Universitas Lampung. Bandar Lampung. $59 \mathrm{hlm}$.

Marlina, M. 1997. Keragaman Bakteri Pelarut Fosfat pada Tanah di Lahan Hutan Primer, Hutan Sekunder, Pertanaman Kopi dan Lahan Kritis di Sumber Jaya Lampung Barat.Skripsi. Universitas Lampung. Bandar Lampung. 67 hlm.
Nurkanto, A. 2007. Identifikasi Aktinomisetes Tanah Hutan Pasca Kebakaran BukitBangkirai Kalimantan Timur dan Potensinya SebagaiPendegradasi Selulosa dan Pelarut Fosfat. Biodiversitas. 8 : 314-319.

Paul, E.A., and F. E. Clark.1989.Soil Microbiology and Biochemistry. Academic Press, Inc. California.273 pp.

PT GMP. 2009. Pengolahan Tanah. http:// www.Gunungmadu.co.id, diakses tanggal $29 \mathrm{Mei}$ 2013.

Santosa, E., T. Prihatini, S. Widati, dan Sukristiyonubowo.1997. Pengaruh Bakteri Pelarut Fosfat Alam terhadap Beberapa Sifat Tanah dan Respon Tanaman Kacang Tanah (Arachis hipogea L.).Prosiding Sem. Nas.Pupuk.HITI:115-121.

Sarno, S.Yusnaini, Dermiyati dan M.Utomo. 2003. Pengaruh Sistem Olah Tanah dan Pemupukan Jangka Panjang terhadap Kandungan Asam Humik dan Fulvik.J Tanah Trop.7:35-42.

Setiadi, Y. 1989. Pemanfaatan Mikroorganisme dalam Kehutanan. Bogor: Institut Pertanian Bogor.

Sucipto.2011. Pengaruh Sistem Olah Tanah dan Aplikasi Mulsa Bagas terhadap Kandungan Biomassa Karbon Mikroorganisme Tanah.Skripsi. Universitas Lampung. Bandar Lampung. $58 \mathrm{hlm}$.

Sutiknowati, L. 2010. Kelimpahan Bakteri Fosfat di Padang Lamun Teluk Banten. Pusat Penelitian Oseanografi-LIPI. 36 (1):21-35.

Umar, I. 2004. Pengolahan Tanah Sebagai Suatu Ilmu :Data, Teori, dan Prinsip-Prinsip. Makalah Pribadi Falsafah Sains (PPS 702).Institut Pertanian Bogor. Bogor.

Utomo, M. 2006. Olah Tanah Konservasi.Hand Out Pengelolaan Lahan Kering Berkelanjutan. Universitas Lampung. $25 \mathrm{hlm}$. 